\title{
Fast Determination of Iodine Number of Biodiesel Using Capillary Zone Electrophoresis with Multi- and Single-Point Calibration
}

\author{
Alysson V. F. Sako ${ }^{a}$ and Gustavo A. Micke ${ }^{\circledR * a}$ \\ ${ }^{a}$ Departamento de Química, Universidade Federal de Santa Catarina, \\ 88040-900 Florianópolis-SC, Brazil
}

\begin{abstract}
A new and fast method was developed to determine the iodine number of biodiesel samples by capillary zone electrophoresis (CZE). In this procedure, the biodiesel sample reacts with Wijs solution in the presence of a catalyst and all the remaining iodine monochloride is converted to the iodide ion, which is quantified by CZE. Only small amounts of sample and reactant are required and $\mu \mathrm{L}$ level amounts of chloroform and Wijs solution. The reaction time was reduced to 3 min and the total analysis time is less than $15 \mathrm{~min}$. The simplicity and speed of the method can be further enhanced by using single-point calibration. The limits of quantification (LOQ) and determination (LOD) values were better than 0.6 and $0.18 \mathrm{~g}$ per $100 \mathrm{~g}$ of biodiesel. Instrumental, intraday, and interday precisions were better than $1.13,1.04$ and $6.02 \%$ relative standard deviation (RSD). The accuracy was statistically verified by comparison with the standard method EN 14111.
\end{abstract}

Keywords: iodine number, biodiesel, capillary zone electrophoresis, Wijs

\section{Introduction}

Biodiesel is an important alternative energy source. Compared to mineral diesel, biodiesel has several advantages, such as renewability, biodegradability, no toxic effects on the environment, ${ }^{1,2}$ compatibility with diesel engines ${ }^{2,3}$ and it usually contains no sulfur or aromatic compounds. ${ }^{1,4}$ Biodiesel is produced by a transesterification reaction, where fatty acids are released from triacylglycerols and these react with alcohols to form the corresponding esters. ${ }^{1,2,5,6}$

It is possible to produce biodiesel through vegetable ${ }^{6}$ or animal ${ }^{7}$ sources. All vegetable oils contain oleic (18:1) and linoleic (18:1(n-19)) fatty acids. Some vegetables, for instance, soy, linseed and canola, contain the $\alpha$-linoleic fatty acid (18:3(n-9)). ${ }^{8}$ Therefore, it is possible to produce biodiesel with a high unsaturated content using vegetable oils. Biodiesels obtained from sunflower, rubber seed, jatropha and cotton seed, for example, may contain more than $70 \mathrm{wt} . \%$ of unsaturated fatty acid methyl esters. ${ }^{9}$ Unsaturated compounds are also presented in the biodiesel produced from animal sources. Tallow biodiesel, for example, has a calculated degree of unsaturation of 1.5, but this is low compared to vegetable biodiesels, such as linseed (3.2) and safflower (2.7). ${ }^{7}$

*e-mail: gustavo.micke@ufsc.br
There is some concern regarding the degree of unsaturation of biodiesel. At high temperatures, polymerization can occur, thickening the fuel. ${ }^{9}$ Consequently, the lubrication in the injection nozzle and the combustion cylinder decreases and this affects the engine performance. ${ }^{5,10,11}$ The engine performance is not always affected by the degree of unsaturation of the biodiesel; however, an increase in this parameter can increase the peak heat release rate, maximum pressure gradient and peak in-cylinder bulk gas-averaged temperature in the engine. ${ }^{12}$ Also, biodiesel samples with a higher degree of unsaturation have exhibited higher $\mathrm{NO}_{\mathrm{x}}$ emission profiles. ${ }^{12,13}$

The degree of unsaturation is evaluated by the iodine number (IN), which is a biodiesel quality parameter and indirectly represents the biodiesel polymerization capacity. ${ }^{5}$ The IN was also correlated to the oxidation stability. However, this correlation has been questioned because there are natural antioxidants and free fatty acids that are not measured by the IN, but which greatly influence the oxidation stability of oils and biodiesel. ${ }^{14}$ Therefore, two oils with the same IN may have different oxidation stability. ${ }^{15}$

European Standards (ENs) and documents published by the American Society for Testing Materials (ASTM) have specified the quality parameters of biodiesel. ${ }^{2,5}$ The IN is established in the standard methods Deutsches Institut für Normung (DIN) EN 14111, ${ }^{16}$ EN $14214^{4}$ and EN 14213, ${ }^{4}$ 
with a limit of $120 \mathrm{~g}$ of $\mathrm{I}_{2}$ per $100 \mathrm{~g}$ of biodiesel. ${ }^{4}$ The Brazilian National Agency of Petroleum, Natural Gas and Biofuels (Agência Nacional do Petróleo, Gás Natural e Biocombustíveis, ANP) only stipulates that the IN value should be reported. ${ }^{17}$ The method EN 14111 is based on the reaction between $\mathrm{ICl}$ and unsaturated long chain alkyl esters. This procedure is commonly known as the Wijs method. ${ }^{16}$ Alternative methods have been developed to determine the IN of biodiesel samples based on potentiometry titration, ${ }^{5}$ gas chromatography, ${ }^{18}{ }^{1} \mathrm{H}$ nuclear magnetic resonance (NMR) spectroscopy, ${ }^{6}$ spot test exploiting of digital images ${ }^{19}$ and a spectrophotometric flow-based procedure. ${ }^{20}$

In this context, a new capillary zone electrophoresis (CZE) method is proposed herein for the determination of the IN of biodiesel samples. The principles of the Wijs method, with adaptations, were applied to obtain a fast, simple, and green analysis method. Detailed information on the method is provided in the following sections.

\section{Experimental}

\section{Chemicals, reagents and samples}

Analytical grade chemicals were obtained. Sodium nitrate solution (1000 $\left.\mathrm{mg} \mathrm{L}^{-1}\right)$, potassium iodide solution (1000 $\left.\mathrm{mg} \mathrm{L}^{-1} \mathrm{I}^{-}\right)$, iodine monochloride $\left(1 \mathrm{~mol} \mathrm{~L}^{-1} \mathrm{ICl}\right.$ in acetic acid, Wijs solution), 6-aminocaproic acid, and sodium acetate were obtained from Sigma-Aldrich. Glacial acetic acid and $\mathrm{HCl}$ were obtained from Synth. Sodium thiosulfate $\left(2 \mathrm{~mol} \mathrm{~L}^{-1} \mathrm{Na}_{2} \mathrm{~S}_{2} \mathrm{O}_{3}\right.$ ) was obtained from Specsol. Biodiesel samples were obtained from 5 different production plants and labeled as A, B, C, D and E. INs of two biodiesel samples (A and $\mathrm{E}$ ) were quantified according to the standard method DIN EN $14111^{16}$ by different laboratories. Sample A was evaluated by 12 laboratories and sample E by one laboratory.

\section{Instrumentation and system configuration}

The method was carried out on an Agilent Technologies capillary electrophoresis system (model $7100 \mathrm{CE}$ ). Two wavelengths were observed in the proposed method: $230 \mathrm{~nm}$ for $\mathrm{I}^{-}$ion (analyte) and $210 \mathrm{~nm}$ for $\mathrm{NO}_{3}{ }^{-}$(internal standard). The applied separation voltage was $-30 \mathrm{kV}$ (negative on the injection side). The cartridge temperature was controlled at $25{ }^{\circ} \mathrm{C}$. Hydrodynamic injection was performed for $5 \mathrm{~s}$ at 50 mbar. A silica capillary $(48.5 \mathrm{~cm} \times 50 \mu \mathrm{m}$ i.d. $)$ with an external coat of polyimide was selected. Before the first use, the capillary was conditioned with $1 \mathrm{~mol} \mathrm{~L}^{-1} \mathrm{NaOH}$ for $30 \mathrm{~min}$ and deionized water for $30 \mathrm{~min}$. Before the first day of use, the capillary was conditioned with $1 \mathrm{~mol} \mathrm{~L}^{-1}$
$\mathrm{NaOH}$, deionized water and background electrolyte (BGE), with 5 min for each step. Between runs, capillary preconditioning was performed by injecting the BGE for 1 min using the flush command (ca. 950 mbar) of the Chemstation software.

\section{BGE development and preparation}

The BGE composition was studied using the Peakmaster 5.3 freeware. ${ }^{21}$ The selected BGE components were 6-aminocaproic acid and $\mathrm{HCl}$. Simulations using 6-aminocaproic acid, ranging from 20 to $100 \mathrm{mmol} \mathrm{L}^{-1}$, and $10 \mathrm{mmol} \mathrm{L}^{-1} \mathrm{HCl}$ were performed. The optimized BGE for this method was composed of $50 \mathrm{mmol} \mathrm{L}^{-1} 6$-aminocaproic acid adjusted to $\mathrm{pH} 5.02$ with $\mathrm{HCl}$.

\section{Catalyst preparation}

The catalyst was developed prior to the experiment and it is composed of sodium acetate and glacial acetic acid. ${ }^{22}$ For this method, the catalyst solution was prepared with approximately $1 \mathrm{~g}$ of sodium acetate dissolved in $5000 \mu \mathrm{L}$ of glacial acetic acid.

Sample preparation procedure and Wijs reagent quantification

Approximately $50 \mathrm{mg}$ of the biodiesel samples were placed in a volumetric flask $(25 \mathrm{~mL})$ and $100 \mu \mathrm{L}$ of the catalyst solution were added to the sample. In the next step, $400 \mu \mathrm{L}$ of $1 \mathrm{~mol} \mathrm{~L}^{-1} \mathrm{ICl}$ dissolved in acetic acid were added. The reaction was carried out in the dark, with occasional stirring, for at least $3 \mathrm{~min}$. Next, $1000 \mu \mathrm{L}$ of 2 mol L-1 sodium thiosulfate were added. The solution was stirred until all of the dark brown drops had disappeared. The addition of some deionized water in this step helps to accelerate the process. The flask volume was completed with deionized water to the meniscus and $500 \mu \mathrm{L}$ of the solution were placed in an Eppendorf tube. To perform the liquid-liquid extraction, $200 \mu \mathrm{L}$ of chloroform were also added to the Eppendorf tube. The tube was vortexed for $10 \mathrm{~s}$ and centrifuged for $60 \mathrm{~s}$ at $14500 \mathrm{rpm}$. After centrifugation, $50 \mu \mathrm{L}$ of the supernatant were diluted with $50 \mu \mathrm{L}$ of $1000 \mathrm{mg} \mathrm{L}^{-1}$ nitrate solution and $900 \mu \mathrm{L}$ of deionized water, and $700 \mu \mathrm{L}$ of the resulting solution were then transferred to a vial for injection into the CE equipment. The Wijs solution was also quantified in triplicate by the same procedure described above, but without the biodiesel sample. The calculated average concentration was used to determine the $\mathrm{ICl}$ added initially to the flasks for the calculation of the IN of the biodiesel samples. 
Validation of the multi-point calibration and single-point calibration methods

The validation was performed for conventional multipoint calibration (MPC) and single-point calibration (SPC). ${ }^{23,24}$ The method parameters of specificity, linearity, linear range, limits of quantification (LOQ) and detection (LOD), accuracy, intraday, interday and instrumental precision $^{25}$ were evaluated. Calibration curves were prepared in triplicate in the range of 10 to $90 \mathrm{mg} \mathrm{L}^{-1}$ of $\mathrm{I}^{-}$. The linearity of the method was observed from the $\mathrm{F}_{\text {calculated }}$ and $\mathrm{r}^{2}$ values. ${ }^{23}$ External calibration curves were prepared with $50 \mathrm{mg} \mathrm{L}^{-1} \mathrm{NO}_{3}^{-}$(internal standard) and $4 \mathrm{mmol} \mathrm{L}^{-1}$ $\mathrm{Na}_{2} \mathrm{~S}_{2} \mathrm{O}_{3}$.

Instrumental precision was evaluated injecting repeatedly $(\mathrm{n}=10)$ a $40 \mathrm{mg} \mathrm{L}^{-1}$ iodide solution. Intraday precision was evaluated through the preparation of each of the calibration curve solutions $(n=8)$ in triplicate. Interday precision was evaluated by preparing the calibration curve solutions on three different days. The results for the precision parameters are given in percentage relative standard deviation (\% RSD) values.

Accuracy was evaluated comparing statistically ( $t$-test) the values obtained for the IN according to the standard method (DIN EN 14111) ${ }^{16}$ for two different samples. LOQ and LOD for the proposed method were calculated considering signal-to-noise $(\mathrm{S} / \mathrm{N})$ ratios of $10: 1$ and $3: 1$ for MPC and calculated according to Olivieri ${ }^{23}$ for SPC.

\section{Results and Discussion}

\section{An overview of the method}

The Wijs reaction involves an electrophilic addition where the double bond is cleaved and both $\mathrm{I}$ and $\mathrm{Cl}$ are added to unsaturated fatty acid chains. ${ }^{26}$ In the conventional Wijs method, the $\mathrm{ICl}$ is added in excess in relation to the sample. After the reaction of $\mathrm{ICl}$ with the unsaturations, $\mathrm{I}^{-}$is added to convert the remaining $\mathrm{ICl}$ to $\mathrm{I}_{2}$ and $\mathrm{Cl}^{-}$, and in the final step $\mathrm{I}_{2}$ is titrated with $\mathrm{S}_{2} \mathrm{O}_{3}{ }^{2-}$ in the presence of starch. The titration ends when the blue color disappears, and it is possible to evaluate the IN by the difference between the initial amount of $\mathrm{ICl}$ added in excess, subtracted from the remaining $\mathrm{ICl}$, determined by the titration. ${ }^{5}$ In the proposed procedure, the Wijs method was used with some adaptations. First, a catalyst was added to accelerate the reaction from 30 to $3 \mathrm{~min} .{ }^{22}$ The volume and catalyst concentrations were prepared considering that the sodium acetate concentration is approximately $3-5 \% \mathrm{~m} / \mathrm{m}$ during the reaction step. A good strategy is to convert the remaining $\mathrm{ICl}$ in the solution to $\mathrm{I}^{-}$and $\mathrm{Cl}^{-}$by adding an excess of $\mathrm{S}_{2} \mathrm{O}_{3}{ }^{2-}$, and then analyze the $\mathrm{I}^{-}$by CZE-UV. Data on half reactions involving $\mathrm{ICl}, \mathrm{S}_{2} \mathrm{O}_{3}{ }^{2-}$ and $\mathrm{I}_{2}$, and their standard reduction potentials ${ }^{27}$ provide information on the global reaction. The calculated global standard reduction potential for the direct reaction between $\mathrm{ICl}$ and $\mathrm{S}_{2} \mathrm{O}_{3}{ }^{2-}$ is positive (Table 1) and, therefore, the reaction is spontaneous. ${ }^{28}$

Table 1. Half-reactions, standard reduction potentials and global standard reaction for the proposed direct reaction between $\mathrm{ICl}$ and $\mathrm{S}_{2} \mathrm{O}_{3}{ }^{2-}$

\begin{tabular}{lc}
\hline Semi-reaction & Standard reduction potential ${ }^{\mathrm{a}} / \mathrm{V}$ \\
\hline $2 \mathrm{ICl}_{(\mathrm{s})}+2 \mathrm{e}^{-} \rightleftharpoons \mathrm{I}_{2}+2 \mathrm{Cl}^{-}$ & $\mathrm{E}_{\text {red }}^{0}=+1.22$ \\
$\mathrm{~S}_{2} \mathrm{O}_{3}{ }^{2-}+3 \mathrm{H}_{2} \mathrm{O} \rightleftharpoons 2 \mathrm{H}_{2} \mathrm{SO}_{3}+3 \mathrm{H}^{+}+4 \mathrm{e}^{-}$ & $\mathrm{E}_{\text {red }}^{0}=-0.40$ \\
$\mathrm{I}_{2(\text { aq })}+2 \mathrm{e}^{-} \rightleftharpoons 2 \mathrm{I}^{-}$ & $\mathrm{E}_{\text {red }}^{0}=+0.62$ \\
\hline $\mathrm{Global}$ reaction $^{2-}$ & Global standard potential / V \\
\hline $2 \mathrm{ICl}_{(\mathrm{s})}+\mathrm{S}_{2} \mathrm{O}_{3}^{2-}+3 \mathrm{H}_{2} \mathrm{O} \rightleftharpoons 2 \mathrm{H}_{2} \mathrm{SO}_{3}+$ & $\mathrm{E}_{\text {global red }}^{0}=+1.44$ \\
$3 \mathrm{H}^{+}+2 \mathrm{I}^{-}+2 \mathrm{Cl}^{-}$ & \\
\hline $\begin{array}{l}{ }^{a} \text { Data adapted from Harris }{ }^{27} \mathrm{E}_{\text {red }}^{0} \text { standard reduction potential; } \mathrm{E}_{\text {global red }}^{0} \\
\text { global standard reduction potential. }\end{array}$
\end{tabular}

Figure 1 shows a simplified model of the method and an electropherogram of sample A. It is possible to determine the IN from the difference between the iodine from the Wijs solution added initially and the remaining $\mathrm{I}^{-}$quantified by CZE-UV.

\section{Background electrolyte optimization}

Peakmaster freeware ${ }^{21}$ is a powerful tool to simulate peak separation in electrophoresis and it contains the values for the $\mathrm{p} K_{\mathrm{a}}$ and ionic mobility $\left(\mu_{\text {ionic }}\right)$ of several organic and inorganic compounds. ${ }^{29}$ The Peakmaster data in this section were obtained from the freeware and the strategy for the BGE development is described below.

Efficient peaks are obtained when the effective mobility $\left(\mu_{\text {eff }}\right)$ of an analyte and its co-ion are similar. ${ }^{29,30}$ Under this condition, the electromigration dispersion (EMD) of the analyte is reduced to almost zero. Therefore, $\mathrm{Cl}^{-}$is a good choice of co-ion for $\mathrm{I}^{-}$because their $\mu_{\text {ionic }}$ values are $-79.1 \times 10^{-9}$ and $-79.6 \times 10^{-9} \mathrm{~m}^{2} \mathrm{~V}^{-1} \mathrm{~s}^{-1}$, respectively. Since $\mathrm{HCl}$ and $\mathrm{HI}$ have the same $\mathrm{p} K_{\mathrm{a}}$, their $\mu_{\text {eff }}$ values are approximately equivalent, independently of the $\mathrm{pH}$. Also, $\mathrm{Cl}^{-}$does not show UV absorbance at the analysis wavelength. Nitrate was selected as the internal standard because of its $\mu_{\text {ionic }}$ value $\left(74.1 \times 10^{-9} \mathrm{~m}^{2} \mathrm{~V}^{-1} \mathrm{~s}^{-1}\right)$ and UV absorbance. There are $\mathrm{S}_{2} \mathrm{O}_{3}{ }^{2-}$ ions present, so these were also considered. The $\mathrm{S}_{2} \mathrm{O}_{3}{ }^{2-}$ is in excess in the solution and, thus, the associated broad peak was expected to hinder the separation. $\mathrm{H}_{2} \mathrm{~S}_{2} \mathrm{O}_{3}$ has two $\mathrm{p} K_{\mathrm{a}}$ values: 0.6 and 1.72 . If the $\mathrm{pH}$ is greater than 2.72 , the $\mathrm{S}_{2} \mathrm{O}_{3}{ }^{2-}$ form represents 


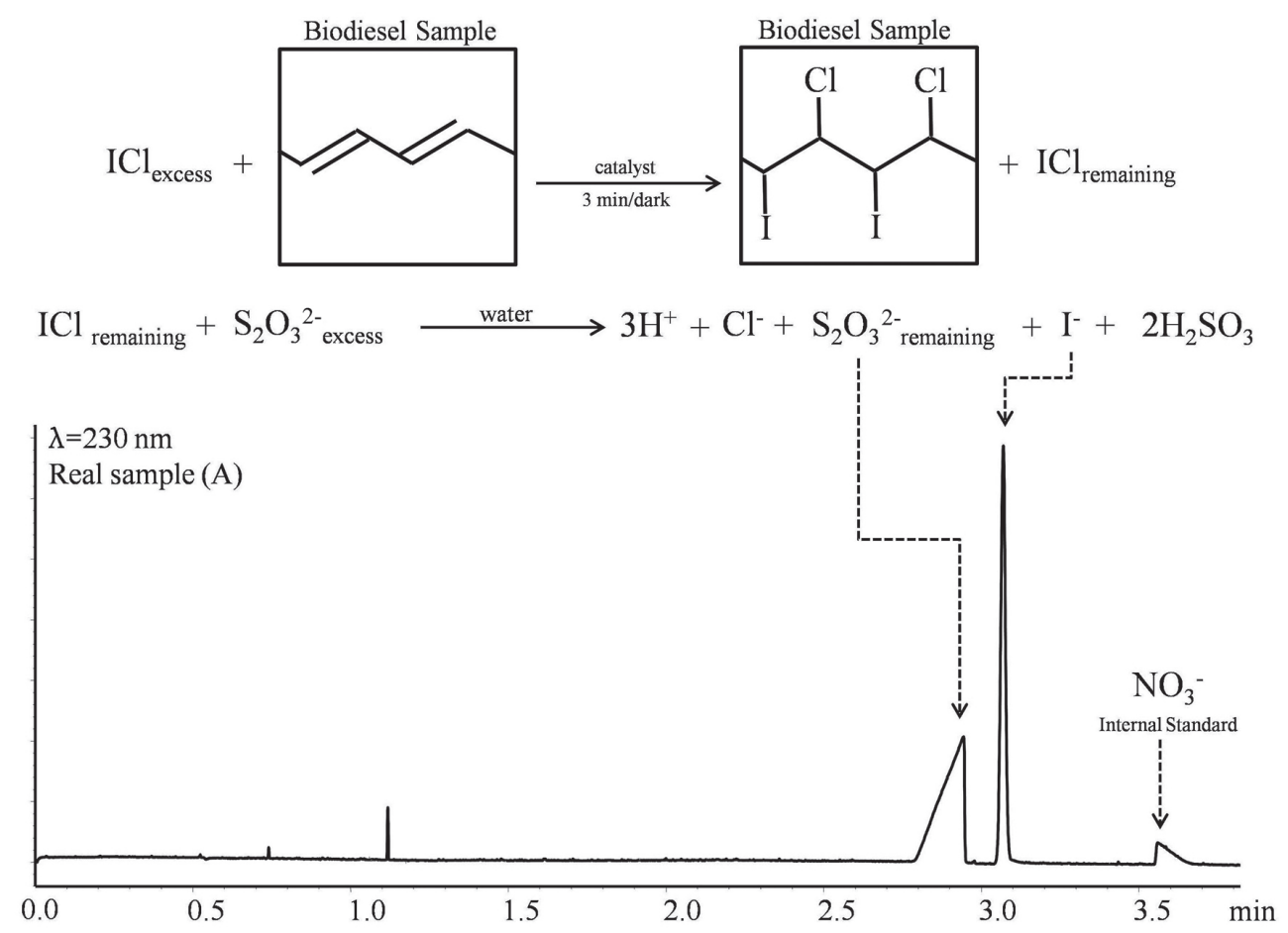

Figure 1. Simplified model for the proposed method. Electropherogram of biodiesel sample A observed at $230 \mathrm{~nm}$. CE configuration: fused-silica capillary of $48.5 \mathrm{~cm} \times 50 \mu \mathrm{m}$ i.d.; hydrodynamic injection: 50 mbar for $5 \mathrm{~s}$; separation voltage: $-30 \mathrm{kV}$; cartridge temperature: $25^{\circ} \mathrm{C}$; BGE composition: $50 \mathrm{mmol} \mathrm{L}{ }^{-1}$ 6-aminocaproic acid adjusted to $\mathrm{pH} 5.02$ with $\mathrm{HCl}$. Detailed information of the method is described in the Experimental section.

practically $100 \%$. The $\mu_{\text {eff }}$ value for anionic species is related to the fraction of its ionized forms ${ }^{31}$ therefore changes in the BGE pH may change the effective mobility of the analyte. Thus, a pH higher than 2.72 was used so that the $\mu_{\text {eff }}$ of the $\mathrm{S}_{2} \mathrm{O}_{3}{ }^{2-}$ ion would be more constant.

In this study, 6-aminocaproic acid was selected because it does not absorb at the wavelength of analysis and it is an amino acid with two $\mathrm{p} K_{\mathrm{a}}$ values: 4.43 and $10.75 .^{32}$ The total charge of 6-aminocaproic acid is 0 or +1 if the $\mathrm{pH}$ is lower than 9.75 , because the amino group is still protonated. Therefore, a 6-aminocaproic acid ion will not act as a co-ion for negative analytes until the $\mathrm{pH}$ is higher than 9.75, when the amino group starts to deprotonate. When there is more than one co-ion for the analyte in the BGE, system peaks that can interfere in the analysis are also present. ${ }^{33}$

The buffer capacity of the BGE in the acid range is between 3.43 and 5.43. To keep the ionic strength low, only $10 \mathrm{mmol} \mathrm{L}^{-1} \mathrm{HCl}$ was used. The buffer capacity increases from 11.81 to $19.07 \mathrm{mmol} \mathrm{L}^{-1}$ when the 6-aminocaproic acid is added at concentrations ranging from 20 to $50 \mathrm{mmol} \mathrm{L}^{-1}$, and at $100 \mathrm{mmol} \mathrm{L}^{-1}$ the buffer capacity does not increase significantly $\left(21.541 \mathrm{mmol} \mathrm{L}^{-1}\right)$. The EMD values for $\mathrm{I}^{-}$, $\mathrm{NO}_{3}{ }^{-}$and $\mathrm{S}_{2} \mathrm{O}_{3}{ }^{2-}$ show no significant variation in the range studied and are all close to zero. Therefore, $10 \mathrm{mmol} \mathrm{L}^{-1} \mathrm{HCl}$ and $50 \mathrm{mmol} \mathrm{L}^{-1} 6$-aminocaproic acids were chosen for the BGE composition. However, it can be observed in Figure 1 that, for $\mathrm{S}_{2} \mathrm{O}_{3}{ }^{2-}$ and $\mathrm{NO}_{3}^{-}$, the experimental peaks are relatively broad in comparison with simulations. Therefore, the experimental and simulated EMDs are different. The $\mathrm{S}_{2} \mathrm{O}_{3}{ }^{2-}$ ion is in excess then the peak broadening is expected. The peak broadening for $\mathrm{NO}_{3}{ }^{-}$is not a problem because it still has an intense UV absorption signal in $210 \mathrm{~nm}$ for the concentration utilized. Table S1 in the Supplementary Information (SI) section contains the data obtained from the simulations carried out in Peakmaster.

\section{Validation of the proposed method and sample analysis}

The results of the method validation are reported in Table 2. Equation 1 was used to evaluate the linearity of the method for MPC and SPC. . $^{2,35}$ The $\mathrm{F}_{\text {calculated }}$ value was lower than $\mathrm{F}_{\text {critical }}=2.74$ (Table $\mathrm{S} 2$, SI section), which means that there is no lack of fit for the regression models. To obtain the response factor $\left(\mathrm{R}_{\mathrm{f}}\right)$ for SPC, equation 2 was plotted using the average responses $\left(\overline{\mathrm{Ar}}_{\mathrm{i}} / \overline{\mathrm{Ar}}_{\mathrm{iNO}_{3}^{-}}\right)$, for each concentration level i of $\mathrm{I}^{-}\left(\mathrm{C}_{\mathrm{i}}\right)$, with a constant concentration of $\mathrm{NO}_{3}^{-}\left(\mathrm{C}_{\mathrm{iNO}_{3}^{-}}\right)$. The average peak areas of $\mathrm{I}^{-}$and $\mathrm{NO}_{3}^{-}$were abbreviated as $\overline{\operatorname{Ar}}_{\mathrm{i}}$ and $\overline{\mathrm{Ar}}_{\mathrm{iNO}}^{-}$, respectively. The response factor was represented by $\mathrm{R}_{\mathrm{f}}$. Based on statistical analysis, ${ }^{34}$ the linear coefficient for SPC was neglected.

$\mathrm{F}_{\text {calculated }}=\frac{\sum_{\mathrm{i}=1}^{\mathrm{p}} \mathrm{m}_{\mathrm{i}}\left(\overline{\mathrm{y}}_{\mathrm{i}}-\hat{\mathrm{y}}_{\mathrm{i}}\right)^{2} /(\mathrm{p}-2)}{\sum_{\mathrm{i}=1}^{\mathrm{p}} \sum_{\mathrm{j}=\mathrm{h}}^{\mathrm{m}_{\mathrm{i}}}\left(\mathrm{y}_{\mathrm{ij}}-\overline{\mathrm{y}}_{\mathrm{i}}\right)^{2} /(\mathrm{m}-\mathrm{p})}$ 
Table 2. Validation parameters for MPC and SPC methods

\begin{tabular}{|c|c|c|}
\hline Parameter & Multi-point calibration (MPC) & Single-point calibration (SPC) \\
\hline Linear regression equation & $\mathrm{Ar}_{\mathrm{I}^{-}} / \mathrm{Ar}_{\mathrm{NO}_{3}^{-}}=0.0125 \mathrm{C}_{\mathrm{I}^{-}}+0.0062$ & $\mathrm{Ar}_{\mathrm{I}^{-}} / \mathrm{Ar}_{\mathrm{NO}_{3}^{-}}=0.6239 \mathrm{C}_{\mathrm{I}^{-}} / \mathrm{C}_{\mathrm{NO}_{3}^{-}}$ \\
\hline Linear range / $\left(\mathrm{mg} \mathrm{L}^{-1}\right)$ & \multicolumn{2}{|c|}{$5.0-90.0$} \\
\hline Linearity & \multicolumn{2}{|c|}{$\mathrm{F}_{\text {calculated }}=0.296<\left[\mathrm{F}_{(0.05,5,14)}=\mathrm{F}_{\text {critical }}=2.958\right] ; \mathrm{r}^{2}=0.9998$} \\
\hline Instrumental precision / (\% RSD) & \multicolumn{2}{|c|}{1.13} \\
\hline Intraday precision / (\% RSD) & \multicolumn{2}{|c|}{$0.036-1.04$} \\
\hline Interday precision / (\% RSD) & \multicolumn{2}{|c|}{$1.50-6.02$} \\
\hline $\mathrm{LOQ}^{\mathrm{b}} /\left(\mathrm{g} \mathrm{I}_{2}\right.$ per $100 \mathrm{~g}$ of biodiesel $)$ & \multicolumn{2}{|r|}{0.165} \\
\hline $\mathrm{LOD}^{\mathrm{c}} /\left(\mathrm{g} \mathrm{I}_{2}\right.$ per $100 \mathrm{~g}$ of biodiesel $)$ & \multicolumn{2}{|r|}{0.055} \\
\hline & \multicolumn{2}{|c|}{ Accurate with $95 \%$ of confidence ( $t$-test) } \\
\hline Accuracy $^{\mathrm{d}}$ & $\begin{array}{c}\text { reference sample A: } \\
t_{\text {calculated }}=-0.87 \\
\quad\left(t_{\text {critical }}=2.16\right) \\
\text { reference sample E: } \\
t_{\text {calculated }}=2.70 \\
\quad\left(t_{\text {critical }}=2.78\right)\end{array}$ & $\begin{array}{c}\text { reference sample A: } \\
t_{\text {calculated }}=-1.72 \\
\quad\left(t_{\text {critical }}=2.16\right) \\
\text { reference sample E: } \\
t_{\text {calculated }}=2.39 \\
\quad\left(t_{\text {critical }}=2.78\right)\end{array}$ \\
\hline
\end{tabular}

${ }^{\text {a Since }}-\mathrm{t}_{\alpha / 2, \mathrm{n}-2}<\mathrm{b}_{0} / \mathrm{s}_{0}<+\mathrm{t}_{\alpha / 2, \mathrm{n}-2}$ (where $\alpha$ is the confidence level; $\mathrm{b}_{0}$ is the intercept from the linear regression; and $\mathrm{s}_{0}$ is the standard error of the intercept from the linear regression), the null hypothesis (intercept $=0$ ) is accepted and single-point calibration is possible; ${ }^{34} \mathrm{~b}$ considering the sample mass and dilution in the "Sample preparation procedure and Wijs reagent quantification" sub-section. Based on S/N ratio of 10:1 for MPC, and based on equations 2 and 4 for SPC. If converted to ICl values, limits of quantification (LOQs) are 0.38 and $0.14 \mathrm{~g}$ per $100 \mathrm{~g}$ of biodiesel for MPC and SPC, respectively; ${ }^{\circ}$ considering the sample mass and dilution in the "Sample preparation procedure and Wijs reagent quantification" sub-section. Based on S/N ratio of 3:1 for external calibration curve, and based on equations 3 and 4 for SPC. If converted to ICl values, limits of detection (LODs) are 0.12 and $0.05 \mathrm{~g}$ per $100 \mathrm{~g}$ of biodiesel for MPC and SPC, respectively; ${ }^{d}$ reference sample A was analyzed by 12 laboratories and reference sample E by 1 laboratory using the DIN EN $14111^{16}$ standard method. $\mathrm{F}_{\text {calculated }}$ and $\mathrm{F}_{\text {critical }}$ : calculated and tabulated (Fisher-Snedecor distribution) F-test values; $\mathrm{r}^{2}$ : coefficient of determination; RSD: relative standard deviation; $t_{\text {calculated }}$ and $t_{\text {critical }}$ : calculated and tabulated Student's $t$-values.

$$
\frac{\overline{\operatorname{Ar}}_{\mathrm{i}}}{\overline{\mathrm{Ar}}_{\mathrm{iNO}_{3}^{-}}}=\mathrm{R}_{\mathrm{f}} \frac{\mathrm{C}_{\mathrm{i}}}{\mathrm{C}_{\mathrm{iNO}_{3}^{-}}}
$$

From equation $1, \mathrm{p}$ is the total number of calibration levels; 1 is the specific calibration level; $\mathrm{m}_{\mathrm{i}}, \overline{\mathrm{y}}_{\mathrm{i}}$ and $\hat{\mathrm{y}}_{\mathrm{i}}$ are the number of replicates, average response and estimated response for a specific calibration level, respectively; $y_{\mathrm{ij}}$ is the experimental response for a specific calibration level and replicate.

The precision parameters were very satisfactory, with the instrumental and intraday precisions being better than $1.13 \%$ RSD and interday precision ranging from 1.50 to $6.02 \%$ RSD. The LOQ and LOD of the proposed method had different values for MPC and SPC. For SPC, equations 3, 4 and 5 were applied as recommended..$^{23}$ Despite the differences between the LOQs and LODs for MPC and SPC, in both cases they were good enough to cover the real range of interest, since a biodiesel sample will rarely have IN values lower than 1 .

$$
\begin{aligned}
& \mathrm{LOD}=\frac{3.3 \mathrm{~S}_{\mathrm{y} / \mathrm{x}}}{\mathrm{A}} \sqrt{1+\mathrm{h}_{0}+1 / \mathrm{I}} \\
& \mathrm{LOQ}=\frac{10 \mathrm{~S}_{\mathrm{y} / \mathrm{x}}}{\mathrm{A}} \sqrt{1+\mathrm{h}_{0}+1 / \mathrm{I}}
\end{aligned}
$$

$$
\mathrm{h}_{0}=\frac{\overline{\mathrm{C}}_{\mathrm{cal}}{ }^{2}}{\sum_{\mathrm{i}=1}^{\mathrm{I}}\left(\mathrm{C}_{\mathrm{i}}-\overline{\mathrm{C}}_{\mathrm{cal}}\right)^{2}}
$$

where $\mathrm{S}_{\mathrm{y} / \mathrm{x}}$ is the residual standard deviation; $\mathrm{A}$ is the slope of the linear regression of equation $2 ; \mathrm{h}_{0}$ is the leverage for the blank sample; I is the total calibration solutions prepared $\left(\mathrm{I}=\mathrm{m}_{\mathrm{i}} \mathrm{p}\right)$; and $\overline{\mathrm{C}}_{\text {cal }}$ is the average concentration of calibration curve levels $\left(\overline{\mathrm{C}}_{\mathrm{cal}}=\sum_{\mathrm{i}=1}^{\mathrm{p}} \mathrm{C}_{\mathrm{i}} / \mathrm{p}\right)$.

The $t$-test results verified the accuracy of the method with a 95\% confidence level using the MPC and SPC models. The calculated IN for the samples using MPC and SPC (Table 3) ranged from $57.25 \mathrm{~g}$ of $\mathrm{I}_{2}$ per $100 \mathrm{~g}$ of sample to values close to $131.60 \mathrm{~g}$ of $\mathrm{I}_{2}$ per $100 \mathrm{~g}$ of sample. Four of the five samples were close to the maximum IN limit stipulated in the EN standards. Figure 1 shows an electropherogram of sample A at $230 \mathrm{~nm}$. The method is also specific for the analyte, which is in agreement with the peak purity of $\mathrm{I}^{-}$provided by the Chemstation software and accuracy results.

The Wijs solution was also quantified using the proposed method since its concentration in the specification ranged from 0.8 to $1.2 \mathrm{~mol} \mathrm{~L}^{-1}$. The concentration determined using the proposed method was $1.04 \pm 0.09 \mathrm{~mol} \mathrm{~L}^{-1}$. This step is important to increase the precision and accuracy of the 
Table 3. IN found using the proposed method for five different biodiesel samples calculated using MPC and SPC methods

\begin{tabular}{lcc}
\hline \multirow{2}{*}{ Biodiesel sample } & \multicolumn{2}{c}{ Iodine number / $\left(\mathrm{g} \mathrm{I}_{2}\right.$ per $100 \mathrm{~g}$ of sample) } \\
\cline { 2 - 3 } & $\begin{array}{c}\text { Multi-point calibration Single-point calibration } \\
\text { (MPC) }\end{array}$ \\
\hline $\mathrm{A}^{\mathrm{a}}$ & $132 \pm 1$ & $131 \pm 1$ \\
$\mathrm{~B}$ & $126 \pm 3$ & $126 \pm 3$ \\
$\mathrm{C}$ & $128 \pm 5$ & $128 \pm 5$ \\
$\mathrm{D}$ & $124 \pm 5$ & $124 \pm 5$ \\
$\mathrm{E}^{\mathrm{b}}$ & $58 \pm 3$ & $57 \pm 3$ \\
\hline
\end{tabular}

aReference method: DIN EN 14111,16 quantified by 12 laboratories. Reference value: $130 \pm 2 \mathrm{~g} \mathrm{I}_{2}$ per $100 \mathrm{~g}$ of sample; ${ }^{\text {breference method: }}$ DIN EN 14111, ${ }^{16}$ quantified by 1 laboratory. Reference value: $62 \pm 1 \mathrm{~g}$ $\mathrm{I}_{2}$ per $100 \mathrm{~g}$ of sample.

reagent. Also, since the Wijs solution passes through the same steps in the quantification of biodiesel samples, this is a manner of compensating for errors associated with the pipetting or dilution of the solutions.

\section{Statistical study of SPC in comparison with MPC}

A statistical study was conducted to compare the quantification by $R_{f}$ and MPC. As previously noted, $R_{f}$ is used in SPC and it can be obtained from the slope of the linear regression using equation 2 . However, SPC is used to avoid the need for the preparation of a calibration curve and reduce the number of experiments. Therefore, the injection of a single level $i$ of the calibration curve should represent the total group of levels and the same sample concentrations as MPC should be found. In other words, instead of using the $\mathrm{R}_{\mathrm{f}}$ measured through the linear regression, it is possible to calculate the response factor for each i calibration level, using equation 2 , directly through the responses $\bar{y}_{i}$ and known $\mathrm{C}_{\mathrm{i}}$ concentrations. This last calculation provides the $\mathrm{p}$ response factors, and each response factor is an $\mathrm{R}_{\mathrm{f}_{\mathrm{i}}}$. In SPC, the aim is to find the i concentration levels where $\mathrm{R}_{\mathrm{f}_{\mathrm{i}}}$ leads to the same sample concentration as MPC. Thus, the $t$-test was applied to verify the levels where $\mathrm{R}_{\mathrm{f}_{\mathrm{i}}}$ gives statistically equivalent concentrations for the samples in relation to MPC. Figure 2 shows the $t$-value calculated for each level i. The $R_{f_{i}}$ values are closer to the $R_{f}$ value when concentrations between 20 and $90 \mathrm{mg} \mathrm{L}^{-1}$ of I- are used in the MPC, because the $t_{\text {calculated }}$ is located within the accepted range $(-2.77$ to +2.77$)$. This does not mean that it is not possible to quantify diluted samples where the response is equivalent to a calibration point of $10 \mathrm{mg} \mathrm{L}^{-1}$ of $\mathrm{I}^{-}$or lower. The results in Figure 2 indicate that, to measure $\mathrm{R}_{\mathrm{f}_{\mathrm{i}}}$ approximately equal to $\mathrm{R}_{\mathrm{f}}$, the analyst should choose a calibration point in the range of 20 to $90 \mathrm{mg} \mathrm{L}^{-1}$ of I- For better results, concentration levels where $t_{\text {calculated }}$ is approximately equal to 0 are the best choice to perform the SPC, which occurs between 30 to $90 \mathrm{mg} \mathrm{L}^{-1}$ of I-

\section{Advantages of CZE-UV for IN determination}

There are several advantages to using CZE to measure the IN. In comparison to visual or coulometric titration methods, CZE has no visual error, low consumption of

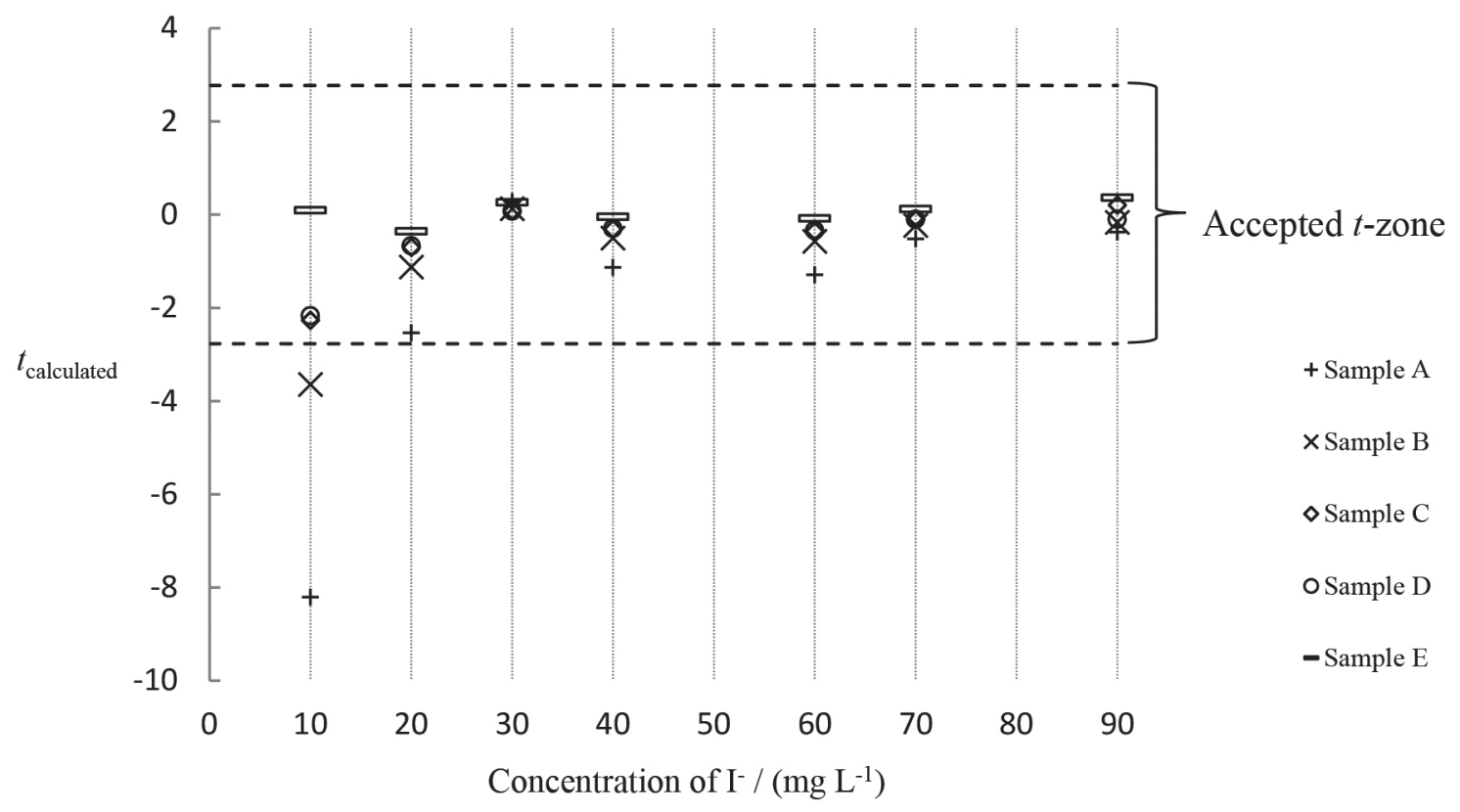

Figure 2. Comparison between MPC and SPC using $t$-test with the response factors for each i level ( $\left.\mathrm{R}_{\mathrm{f}_{\mathrm{i}}}\right)$. Between the accepted $t$-zone, $\mathrm{R}_{\mathrm{f}}$ is approximately equal to $\mathrm{R}_{\mathrm{f}_{\mathrm{i}}}$ and SPC is statistically equivalent to the MPC results for biodiesel sample quantifications. 
solvent, reagents and sample (from $\mathrm{mL}$ to $\mu \mathrm{L}$ ) and better analytical frequency and specificity. The CZE-UV system has low cost operation compared to gas chromatography and ${ }^{1} \mathrm{H}$ NMR spectroscopy. Also, the CE equipment has a powerful versatility and can be used to perform important analysis for the quality control of biodiesel, for instance, the determination of inorganic cations, ${ }^{36,37}$ anions ${ }^{37}$ and free and total glycerol. ${ }^{38}$

\section{Conclusions}

The proposed method showed good performance in the determination of the IN of biodiesel samples by CZE-UV. In comparison with EN standard methods, the use of Wijs solution and chloroform was reduced from $\mathrm{mL}$ to $\mu \mathrm{L}$ levels. The sample preparation is easy, simple and fast. The catalyst shows good performance and the reaction time was reduced from 30 to $3 \mathrm{~min}$. Also, the method has clear advantages in terms of operational costs, reagent and solvent consumption, waste generation and analytical frequency in comparison with other published methods. Both calibration methods are accurate at the 95\% confidence level and statistically equivalent to the standard method EN 14111. The statistical studies verified the applicability of the SPC model, which can be used for faster IN determination compared to MPC, but shows the same performance if the recommended considerations are taken into account.

\section{Supplementary Information}

Supplementary information is available free of charge at http://jbcs.sbq.org.br as PDF file.

\section{Acknowledgments}

The authors would like to thank INCT-Catálise, Conselho Nacional de Desenvolvimento Científico e Tecnológico (CNPq) and Coordenação de Aperfeiçoamento de Pessoal de Nível Superior (CAPES) for the scientific incentives and financial support.

\section{References}

1. Peiter, A. S.; Lins, P. V. S.; Meili, L.; Soletti, J. I.; Carvalho, S. H. V.; Pimentel, W. R. O.; Meneghetti, S. M. P.; J. King Saud Univ., Sci., in press, DOI: 10.1016/j.jksus.2018.01.010.

2. Thoai, D. N.; Kumar, A.; Prasertsit, K.; Tongurai, C.; Energy Procedia 2017, 138, 544.

3. Efe, Ş.; Ceviz, M. A.; Temur, H.; Renewable Energy 2018, 119, 142.
4. Saluja, R. K.; Kumar, V.; Sham, R.; Renewable Sustainable Energy Rev. 2016, 62, 866.

5. Tubino, M.; Aricetti, J. A.; Fuel 2013, 103, 1158.

6. Shimamoto, G. G.; Tubino, M.; Talanta 2018, 179, 816.

7. Balakrishnan, A.; Parthasarathy, R. N.; Gollahalli, S. R.; Fuel 2016, $182,798$.

8. Dijkstra, A. J. In Encyclopedia of Food and Health; Caballero, B.; Finglas, P. M.; Toldrá, F., eds.; Academic Press: Oxford, 2016, p. 357-364.

9. Gopinath, A.; Puhan, S.; Govindan, N.; Int. J. Energy Environ. 2010, 1, 411.

10. Leung, D. Y. C.; Koo, B. C. P.; Guo, Y.; Bioresour. Technol. 2006, 97, 250.

11. Kalayasiri, P.; Jeyashoke, N.; Krisnangkura, K.; J. Am. Oil Chem. Soc. 1996, 73, 471.

12. Benjumea, P.; Agudelo, J. R.; Agudelo, A. F.; Energy Fuels 2011, 25, 77.

13. Altun, Ş.; Fuel 2014, 117, 450.

14. Lapuerta, M.; Rodríguez-Fernández, J.; de Mora, E. F.; Energy Policy 2009, 37, 4337.

15. Knothe, G.; J. Am. Oil Chem. Soc. 2002, 79, 847.

16. En 14111: Fat and Oil Derivatives - Fatty Acid Methyl Esters (FAME), Determination of Iodine Value, European Committee for Standardization, Berlin, 2003.

17. Agência Nacional do Petróleo, Gás Natural e Biocombustíveis (ANP); Resolução ANP No. 7, de 19.3.2008-DOU 20.3.2008.

18. Bondioli, P.; Della Bella, L.; Gallonzelli, A.; Riv. Ital. Delle Sostanze Grasse 2011, 88, 77.

19. Soares, S.; Lima, M. J. A.; Rocha, F. R. P.; Microchem. J. 2017, $133,195$.

20. Pereira, A. C.; Rocha, F. R. P.; Anal. Chim. Acta 2014, 829, 28.

21. Jaroš, M.; Hruška, V.; Štědrý, M.; Zusková, I.; Gaš, B.; Electrophoresis 2004, 25, 3080.

22. Makino, A.; US pat. 4297106 A 1980.

23. Olivieri, A. C.; Anal. Chim. Acta 2015, 868, 10.

24. Danzer, K.; Currie, L. A.; Pure Appl. Chem. 1998, 70.

25. Taverniers, I.; De Loose, M.; Van Bockstaele, E.; TrAC, Trends Anal. Chem. 2004, 23, 535.

26. De La Mare, P. B. D.; Bolton, R.; Electrophilic Additions to Unsaturated Systems, $2^{\text {nd }}$ ed.; Elsevier Science:Amsterdam, 2013.

27. Harris, D. C.; Quantitative Chemical Analysis, $7^{\text {th }}$ ed.; W. H. Freeman: New York, 2007.

28. Bratsch, S. G.; J. Phys. Chem. Ref. Data 1989, $18,1$.

29. Beneš, M.; Svobodová, J.; Hruška, V.; Dvořák, M.; Zusková, I.; Gaš, B.; J. Chromatogr. A 2012, 1267, 109.

30. Shallan, A.; Guijt, R.; Breadmore, M. In Encyclopedia of Forensic Sciences, $2^{\text {nd }}$ ed.; Siegel, J. A.; Saukko, P. J.; Houck, M. M., eds.; Academic Press: Waltham, 2013, p. 549-559.

31. Dolzan, M. D.; Spudeit, D. A.; Azevedo, M. S.; Costa, A. C. O.; de Oliveira, M. A. L.; Micke, G. A.; Anal. Methods 2013, 5,6023 . 
32. O'Neil, M. J.; The Merck Index: An Encyclopedia of Chemicals, Drugs, and Biologicals; Merck \& Co.: Whitehouse Station, 2013.

33. Štědrý, M.; Jaroš, M.; Gaš, B.; J. Chromatogr. A 2002, 960, 187.

34. Bánfai, B.; Kemény, S.; J. Chemom. 2012, 26, 117.

35. Faria, A. F.; de Souza, M. V. N.; de Oliveira, M. A. L.; J. Braz. Chem. Soc. 2008, 19, 389.
36. Piovezan, M.; Costa, A. C. O.; Jager, A. V.; de Oliveira, M. A. L.; Micke, G. A.; Anal. Chim. Acta 2010, 673, 200.

37. Nogueira, T.; do Lago, C. L.; Microchem. J. 2011, 99, 267.

38. Gonçalves Filho, L. C.; Micke, G. A.; J. Chromatogr. A 2007, 1154, 477.

Submitted: June 5, 2018

Published online: September 17, 2018 